\title{
Profile of Caesarean Section in Kirtipur Hospital
}

\author{
Pradhan $\mathbf{P}^{1}$, Shrestha $\mathbf{S}^{1}$, Rajbhandari $\mathbf{P K}^{2}$, Dangal $\mathbf{G}^{3}$ \\ ${ }^{1}$ Department of Obstetrics and Gynaecology, Kirtipur Hospital, ${ }^{2}$ Department of Anesthesiology, Kirtipur Hospital, Kir- \\ tipur, ${ }^{3}$ Department of Obstetrics and Gynaecology, Kathmandu Model Hospital, Kathmandu, Nepal
}

Received: February 10, 2014; Accepted: August 17, 2014

\begin{abstract}
Aims: This study was done to find out the incidence and outcome of caesarean sections done at Kirtipur Hospital.
Methods: This was a retrospective study conducted from 1st January 2009 to 31st December 2013. Case files of 660 patients who underwent caesarean section for various indications were analyzed for incidence, indication of caesarean section, booking status, parity, and maternal and fetal outcomes.

Results: Out of 1295 deliveries, 50.9\% ( $\mathrm{n}=660)$ had caesarean section. Most of the caesarean section was done for fetal distress $(40.2 \% ; n=265)$ and on account of previous history of caesarean section $(13.5 \% ; n=89)$. Majority of caesarean section $(44.4 \%, n=293)$ was done in age group of $25-29$ years. Among them, $65.9 \%(n=435)$ were nulliparous. There were $35.3 \%$ $(\mathrm{n}=563)$ booked cases. Emergency caesarean sections were performed in $62.4 \%(\mathrm{n}=412)$ cases. Maternal morbidity was less $(7.2 \%, \mathrm{n}=48)$.
\end{abstract}

Conclusions: The study showed high rate of caesarean section. The most common indication was fetal distress. Post-operative complications and fetal outcome were within acceptable range.

Keywords: caesarean section; indication of caesarean section; maternal and fetal outcomes.

\section{INTRODUCTION}

Caesarean section is one of the commonly performed surgical procedures in obstetrics and is certainly one of the oldest operations in surgery. The objective of caesarean section in the ancient world was mainly postmortem delivery of dead or alive fetus. ${ }^{1}$ The incidence of caesarean section varies from hospital to hospital within a country and across nations. ${ }^{2}$ There is no consensus about what the ideal caesarean section rate should be. World Health Organization states that there are no additional health benefits associated with caesarean section rates above $10-15 \%$. But caesarean section rates have increased remarkably worldwide. ${ }^{3-5}$ The reason for this marked increase has not been completely evaluated but the possible explanations are the use of electronic fetal monitoring which helps in early detection of fetal distress and results in increased number of caesarean section, increasing use of caesarean section for most of the breeches and practice of repeat caesarean section. ${ }^{6-8}$ In this

\section{CORRESPONDENCE}

Dr Peru Pradhan

Department of Obstetrics and Gynaecology,

Kirtipur Hospital, Kirtipur, Nepal.

Email: pradhanperu@gmail.com

Phone: +977-9851170155 study, we intended to review the caesarean section incidence and profiles of the parturients visiting at Kirtipur Hospital.

\section{METHODS}

This study was undertaken in a hospital where there are large constraints in the form of the sociodemographic characteristics of patient it caters for, poor availability of manpower and facilities. This is a retrospective analysis of all the caesarean sections carried out at Kirtipur Hospital from $1^{\text {st }}$ January 2009 to $31^{\text {st }}$ December 2013. The case files of the patients were retrieved from the record room and analyzed for patient's age, parity, antenatal booking status, incidence, indications and type of caesarean sections, fetal APGAR score, and maternal morbidity and mortality rates. Ethical approval was taken from institutional review committee of phect-NEPAL under which Kirtipur hospital is run. The data was entered into computer and was analyzed accordingly.

\section{RESULTS}

There were 1295 deliveries during the study period. There were 660 caesarean sections accounting for a 
caesarean section rate of $50.9 \%$. Out of 660 cases reviewed, $412(62.5 \%)$ had emergency caesarean section and $248(37.6 \%)$ were elective. Five hundred and sixty three cases $(85.3 \%)$ had antenatal care and $97(14.7 \%)$ did not have antenatal care.

Thirty-one (4.7\%) patients among caesarean section were adolescents and majority $(65.9 \%)$ of the women were primipara (Table 1).

\begin{tabular}{|lll|}
\hline \multicolumn{3}{|l|}{$\begin{array}{l}\text { Table 1. Demographic characteristics of women } \\
(\mathrm{n}=660) \text {. }\end{array}$} \\
\hline Age in years & Number & $(\mathbf{\%})$ \\
$<=19$ & 31 & $(4.7)$ \\
$20-24$ & 186 & $(28.2)$ \\
$25-29$ & 293 & $(40.4)$ \\
$30-34$ & 116 & $(17.6)$ \\
$35-39$ & 31 & $(4.7)$ \\
$>=40$ & 3 & $(0.4)$ \\
$\mathrm{P}_{0}$ & 435 & $(65.9)$ \\
$\mathrm{P}_{1}$ & 193 & $(29.2)$ \\
$\mathrm{P}_{2}$ & 29 & $(4.4)$ \\
$\mathrm{P}_{3}$ & 2 & $(0.3)$ \\
$\mathrm{P}_{4}$ & 1 & $(0.15)$ \\
\hline
\end{tabular}

The most common indication for caesarean section was fetal distress followed by previous caesarean section and others (Table 2).

\begin{tabular}{|llc|}
\hline \multicolumn{3}{|l|}{ Table 2. Indications for caesarean section $(\mathrm{n}=660)$. } \\
\hline Indications & Number & $(\mathbf{\%})$ \\
Fetal distress & 265 & $(40.2)$ \\
Previous caesarean section & 89 & $(13.5)$ \\
Oligohydramnios & 59 & $(8.9)$ \\
Non-progress of labour & 52 & $(7.8)$ \\
Failed induction & 39 & $(5.9)$ \\
Breech presentation & 35 & $(5.3)$ \\
Cord round neck & 28 & $(4.2)$ \\
Cephalopelvic disproportion & 19 & $(2.8)$ \\
Pregnancy induced & 18 & $(2.7)$ \\
hypertension/preeclampsia & & \\
Bad obstetric history & 10 & $(1.5)$ \\
Malpresentation & 19 & $(2.8)$ \\
Antepartum haemorrhage & 8 & $(1.2)$ \\
Maternal request & 7 & $(1)$ \\
Intrahepatic cholestasis & 5 & $(0.7)$ \\
Others & 9 & $(1.45)$ \\
\hline
\end{tabular}

Post-operative complications were mainly minor and minimal $(n=48 / 660,7.2 \%)$ as shown in Table 3. However, one patient having severe PPH with placenta increta had to undergo subtotal hysterectomy.

\begin{tabular}{|lcc|}
\hline \multicolumn{3}{|l|}{ Table 3. Post-operative morbidity of patients } \\
$(\mathrm{n}=48 / 660,7.2 \%)$.
\end{tabular}

Majority of the neonates (93\%) had good APGAR score (7-10) at 1 minute (Table 4).

\begin{tabular}{|lllll|}
\hline Table 4. APGAR score of neonates $(\mathrm{n}=663)$. \\
\hline APGAR score & $\mathbf{1}$ $\mathbf{m i n}$ & $\mathbf{5}$ & $\mathbf{5} \mathbf{~ m i n}$ & $\mathbf{\%}$ \\
$0-3$ & 0 & & 0 & \\
$4-6$ & 45 & $(6.8)$ & 5 & $(0.8)$ \\
$7-10$ & 618 & $(93.2)$ & 658 & $(99.2)$ \\
\hline
\end{tabular}

\section{DISCUSSION}

This study showed a caesarean section incidence of $50.9 \%$ during the study period which is slightly lower than $51.43 \%$ as reported by Nazir et al. ${ }^{8}$ However, it is higher than the reports from other studies. . $^{1,4-6,9-16}$

The frequency of caesarean section depends on the inherent characteristics of the obstetric population, socio-demographic pattern, referral role of the hospital, department's policies regarding management of cases of dystocia, breech, fetal distress and previous caesarean section, physician factor, medicolegal aspects and consideration of maternal choice and wishes. ${ }^{1}$ The higher rate of caesarean section in this study might be due to unavailability of fetal scalp blood sampling for meconium stained liquor, uncertainty of fetal outcome for cord round the neck, bad obstetric history, oligohydramnios and maternal and fetal morbidity and risk of rupture of uterus in previous section patients.

In our study, $4.7 \%$ caesarean sections were performed in adolescent age group ( $<=19$ years) which is much lower than $25.5 \%$ reported by Liu et $\mathrm{al}^{9}$ and higher than $2.7 \%$ reported by Ugwu et al. ${ }^{2}$ Majority of the patients who underwent caesarean sections were in 
the age group of 25-29 years, i.e. $44.4 \%$, which is slightly higher than $40.3 \%$ reported by Ugwu et al. ${ }^{2}$ The caesarean section rate of $65.9 \%$ in primigravida was higher than the reports from other studies. ${ }^{1,2,8,17,18}$ This is unacceptably high because of the implications of caesarean section on the future reproductive career of these groups of patients.

The study showed that the most common indication for caesarean section was fetal distress (Table 2), accounting for $40.2 \%$ sections, which was higher than $9.6 \%$ as reported by Geidam et al, ${ }^{1} 19.2 \%$ reported by Ugwu et $\mathrm{al}^{2}$ and $14.4 \%$ reported by Shamshad. ${ }^{6}$ Second common indication of caesarean section was repeat caesarean section, i.e. $13.5 \%$, which was lower than that reported by other authors. ${ }^{1,6,8,20}$ In our study, failure to progress for labour was $7.8 \%$ which is lower than $12 \%$ as reported by Shamshad. ${ }^{6}$ This study showed caesarean section for breech in 5.3\%, which was higher than $2.1 \%$ as reported by Ugwu et $\mathrm{al}^{2}$ and lower than $10.2 \%$ as reported by Shamshad et al. ${ }^{6}$ In our study, $1 \%$ caesarean section was done upon maternal request which was lower than $9.07 \%$ in the study by Gao et al. ${ }^{3}$

Any surgical procedures are associated with some kind of morbidity and mortality. Obstetric patients are at high risk for these complications. Any morbidity during the post-operative period puts extra psychological stress to the patients and to their family and as well to the doctor. Moreover, it is associated with extra financial burden. However, there was no maternal mortality during the study period. Maternal morbidity rate (Table 3 ) was $7.2 \%$ $(\mathrm{n}=48 / 660)$ which is less than $20 \%$ as reported by Ali et al. ${ }^{20}$ Krebs and Langhoff-Roos reported low maternal morbidity in elective caesarean section. ${ }^{15}$ Among the maternal morbidity, $39.6 \%$ were pyrexia which was higher than $24 \%$ reported by Ugwu et al. ${ }^{2}$ Postpartum haemorrhage is an important cause for the maternal mortality, especially in developing countries like Nepal. Ten cases out of 48 had postpartum haemorrhage accounting for $20.8 \%$ of morbidity in our study but Nazir et $\mathrm{al}^{8}$ reported only $0.27 \%$ cases of postpartum haemorrhage. Among the 48 patients, $9 \%$ had wound infection, which was lower than $10.3 \%$ and $27.1 \%$ as was reported by Nazir et $\mathrm{al}^{8}$ and Ali et al, ${ }^{20}$ respectively. In our study, 412 (62.5\%) underwent emergency caesarean section. This rate was lower than the rates in other studies, i.e. $79.4 \%{ }^{1}$ and $82.07 \% .{ }^{8}$ Antenatal care is important aspect to reduce pregnancy-related morbidity and mortality and has impact on feto-maternal outcome. This report showed antenatal booking status of the mother in $85.3 \%$, which was higher than the rates in other studies, i.e. $26 \%,{ }^{8} 78.9 \%,{ }^{1}$ and $58.5 \%{ }^{2}$

Overall APGAR scores of neonates were good (Table 4). Majority had APGAR scores of 7-10 at 1 and 5 minutes. Neonatal outcome was satisfactory.

\section{CONCLUSIONS}

In keeping with the increasing incidence of caesarean section globally, a high incidence of caesarean section was recorded in this study. Fetal distress was the most common indication for caesarean section. Maternal request was respected and one percent of caesarean section was done for that. Maternal and neonatal outcome was satisfactory.

\section{DISCLOSURE}

The authors report no conflicts of interest in this work.

No violation of human rights and safety.

Funding: Nil

\section{REFERENCES}

1. Geidam AD, Audu BM, Kawuwa BM, Obed JY. Rising trend and indications of caesarean section at the University of Maiduguri Teaching Hospital, Nigeria. Ann Afr Med. 2009;8:127-32.

2. Ugwu EOV, Obioha KCE, Okezie OA, Ugwu AO. The five-year survey of caesarean delivery at a Nigerian tertiary hospital. Ann Med Health Sci Res. 2011;1:77-83.

3. Gao Y, Xue Q, Chen G, Stone P, Zhao M, Chen Q. An analysis of the indications for caesarean section in teaching hospital in China. Eur J Obstet Gynecol Reprod Biol. 2013;170:414-8.
4. Mehta A, Apers L, Verstraelen H, Temmerman M. Trends in caesarean section rates at a maternity hospital in Mumbai, India. J Health Popul Nutr. 2001; 19(4):306-12.

5. Nwosu C, Agumor K, Aboyeji AP, Ijaiya MA. Outcome of caesarean section in a sub-urban secondary health care facility in Nigeria. Niger Med Pract. 2004;46:77-9.

6. Shamshad M. Factors leading to increased caesarean section rate. Gomal J Med Sci. 2008;6:1-5.

7. Okonkwo NS, Ojengbede OA, Morhason-Bello IO, Adedokun BO. Maternal demand for caesarean section: perception and willingness to request by Nigerian antenatal clients. Int $\mathrm{J}$ Womens Health. 2012;4:141-8. 
8. Nazir A, Razia M. A study of caesarean birth in a teaching hospital. Pakistan J Med Res. 2002;41:118-22.

9. Liu S, Rusen ID, Joseph KS, Liston R, Kramer MS, Wen SW et al. Recent trends in caesarean delivery rates and indications for caesarean delivery in Canada. J Obstet Gynaecol Can. 2004;26:735-42.

10. Zhang J, Troendle J, Reddy UM, Laughon SK, Branch DW, Burkman R, et al. Contemporary caesarean section delivery practice in the United States. Am J Obstet Gynecol. 2010;203:326.e1-326.e10.

11. Barbadoro P, Chiatti C, D'Errico MM, Di Stanislao F, Prospero E. Caesarean delivery in south Italy: women without choice.A cross sectional survey. PLoSOne. 2012; 7:e43906.

12. Lee YM, D'Alton ME. Caesarean delivery on maternal request: the impact on mother and newborn. Clin Perinatol. 2008;35:505-18

13. Tan WC, Devendra K, Tan AS. Changing trends in indication for caesarean sections in a tertiary hospital. Ann Acad Med Singapore. 2003;32:299-304
14. Sperling LS, Henriksen TB, Ulrichsen H, Hedegard M Moller H, Hansen V et al. Indications for caesarean section in singleton pregnancies in two Danish counties with different caesarean section rates. Acta Obstet Gynecol Scand. 1994; 73:129-35.

15. Krebs L, Langhoff-Roos J. Elective caesarean delivery for term breech. Obstet Gynecol. 2003;101:690-6.

16. Aisien AO, Lawson JO, Adebayo AA. A five-year appraisal of caesarean section in a northern Nigeria university teaching hospital. Niger Postgrad Med J. 2002;9:146-150.

17. Mesleh RA, Asiri F, Al-Naim MF. Caesarean section in the primigravid. Saudi Med J. 2000;21:957-9.

18. Khashoggi T, Soltan MH, Al Nuaim L, Addar M, Chowdhury N, Adelusi B. Primary caesarean section in King Khalid University Hospital: indications and obstetric outcome. Ann Saudi Med. 1995; 15:585-8.

19. Penn Z, Ghaem-Maghami S. Indications for caesarean section. Best Pract Res Clin Obstet Gynaecol. 2001;15:1-15.

20. Ali Y. Analysis of caesarean delivery in Jimma Hospital, southwestern Ethiopia. East Afr Med J. 1995;72:60-3. 